Theodoret of Cyrus. An Access to the polyphonic context of Antiochia Bergjan, Silke-Petra

Posted at the Zurich Open Repository and Archive, University of Zurich ZORA URL: https://doi.org/10.5167/uzh-206965

Journal Article

Published Version

Originally published at:

Bergjan, Silke-Petra (2019). Theodoret of Cyrus. An Access to the polyphonic context of Antiochia. Evangelische Theologie, 79(5):377-384. 


\title{
Theodoret of Cyrus.
}

\section{An Access to the polyphonic context of Antiochia}

\author{
Silke-Petra Bergjan
}

\begin{abstract}
Polyphonie im Fall Theodorets lässt sich beziehen auf den vielstimmigen Kontext, den wir in seiner Wirkungsstätte Antiochia im 5. Jahrhundert antreffen. Polyphonie kann aber auch das Zusammenspiel der verschiedenen dogmatischen Themen bei Theodoret meinen. Im Folgenden sollen seine Äußerungen zur Providenz Gottes einen Einblick in seine Person geben und eine breitere Perspektive ermöglichen, die aus der Engführung auf cyrillische Themen herausführt. Die Christologie ist für Theodoret Teil der Providenz Gottes. Theodoret äussert sich in drei Schriften zur Providenz Gottes: Graecarum affectionum curatio, De providentia orationes decem und Haereticarum fabularum compendium. Die Texte zeigen, dass es in Antiochia eine Diskussion um die Rede vom Fleisch Christi als Hülle der Gottheit gegeben hat, dass Theodoret hiervon Distanz nimmt und sich ganz auf die Menschwerdung als Annahme der ganzen menschlichen Natur konzentriert.
\end{abstract}

If there is one question with which studies of Theodoret over the past centuries have grappled repeatedly, it is that of his theological profile, specifically his disputed orthodoxy as an exponent of Antiochene theology. With Cyrilian orthodoxy as the yardstick, virtually every account of Theodoret's theology indulges in strong value judgements. The least negative thing that Opitz can bring himself to say is: »Theodoret was never a consistent proponent of Antiochene theology. He never entirely approved of the theology of Nestorius. $\ll^{1}$ Alternatively, scholars have granted that Theodoret's thinking underwent further development in the post-Ephesus period that saw him turn to Cyrilian orthodoxy; ${ }^{2}$ at the very least, they view him as well-intentioned. Even Paul Clayton refers to "major improvement « in Theodoret's late works, though this does nothing to change his assessment: » Theodoret still seems totally unable to say that the Logos suffers and dies on the cross. As before, this is always the function of the humanity. In other words, a true communicatio idiomatum still does not appear ... I conclude that for all his careful expressions, all his careful avoiding these sconcrete terms< such as rassumed man<, Theodoret's Christology in the Eranistes is still exactly the same as in his pre- 432 works. " ${ }^{3}$ For Clayton, this is a bad thing and merely shows that, despite all the efforts to rehabilitate his orthodoxy, Theodoret learned nothing from Cyril. Clayton can do no more than repeatedly affirm Theodoret's shortcomings.

1. H.-G. Opitz, Theodoretos von Kyros, RECA II.5, 1934, Sp.1704.

2. M. Richard, Notes sur l'évolution doctrinale de Théodoret, in: RSPhTh 25, 1936, 459-481.

3. P. B. Clayton, The Christology of Theodoret of Cyrus. Antiochene Christology from the Council of Ephesus (431) to the Council of Chalcedon (451), Oxford 2007.

Evang. Theol. 79. Jg., Heft 5, S. 377-384, ISSN 0014-3502

(C) 2019 by Gütersloher Verlagshaus, Gütersloh, in der Verlagsgruppe Random House GmbH, München 
My own preferences are rather different. I would like to be able to present a Theodoret in the tradition of Theodore, but that would merely mean replacing one value judgement that privileges Cyrilian orthodoxy with one inclined towards Antiochene orthodoxy. What would an alternative picture that sets aside preferences and orthodoxies look like? If we drop the Cyrilian paradigm in our portrayals of Theodoret then we are forced to rethink our criteria for the dating of his writings. The evaluation of Theodoret's theology in terms of progress and development of ideas has a very limited basis.

The Antiochene church was anything but homogenous or unified. Cyrus, where Theodoret became bishop in 432, was part of the metropolitan area of Hierapolis (Province Syria Euphratensis). Alexander of Hierapolis who heralded the belated arrival of the Oriental representatives in Ephesus and played an important role there more generally, appears shortly afterwards opposing the politics of John of Antioch and, along with Meletius of Mopsuestia, was one of the chief exponents of Antiochene theology who refused to compromise, rejected all communion with the "heretic " Cyril of Alexandria and spurned the peace formula of $433 .{ }^{4}$ This cost both,oth of them, Alexander and Meletius, their bishoprics and forced them into exile along with thirteen other Antiochene bishops. ${ }^{5}$ As his letters show, ${ }^{6}$ Theodoret long continued to be loyal to Alexander, under whom he served as suffragan bishop. One third of Theodoret's letters in the Collectio Casinensis is addressed to Alexander. But Theodoret ultimately switched sides, supported John and came to terms with the Union. ${ }^{7}$ Theodoret was not among the bishops who were willing to risk their office, but gave priority to ensuring that the Antiochene theology would survive. Theodorets role in these years consisted in obtaining concessions for the group around Alexander von Hierapolis. Shortly before the edict was carried out against the recalcitrant bishops, he convinced a number of them to join the side of John. ${ }^{8}$

In addition, we can conclude from the letters and the acts of the synod of 449 that support for Cyril of Alexandria came also from within Antioch. At least some of the people mentioned by Theodoret who brought forward false accusations, slander, and calumnies originated from Antioch and the larger Syrian area. Theodoret expresses his disappointment that after he was sentenced to being confined to Cyrus his own clergy switched sides or withdrew into silence or only now showed their real face. ${ }^{9}$ Yet another group comprises the Antioch Apollinarians. In his church history, Theodoret states that in 428 Bishop Theodotus of Antioch admitted a significant number of Apollinarians into the majority church of Antioch. ${ }^{10}$ Elsewhere I have suggested

4. ACO I,4,146,3; 147; 153.

5. ACO I, 4,279 .

6. Théodoret de Cyr. Correspondance, ed. Y. Azéma, 4 vols., SC 40, 98, 111, 429, Paris 1955-1998. On the letters see P. Allen, The Syrian Church Through Bishops's Eyes. The Letters of Theodoret of Cyrrhus and Severus of Antioch, in: StPatr 42, 2006, 3-22.

7. SC $429,27=$ ACO I, 4,234

8. SC 429, 34 = ACO I,4,256. On these events see: A. M. Schor, Theodoret's people. Social networks and religious conflicts in late Roman Syria, Berkeley 2011. On Theodoret's further involvement in church politics see: G. A. Bevan: Theodoret of Cyrrhus and Syrian Episcopal Elections, in: J. Leemans, P. van Nuffelen (ed.), Episcopal Elections in Late Antiquity, AKG 119, Berlin/ NewYork 2011, 61-87.

9. Cf. for example ep. 84 (SC 98, 220, 2-9), 85 (SC 98, 224,17-24), 87 (SC 98, 232,22-234,1), ep. 125 (SC 111, 96,11-17), 131 (SC 111,17-21).

10. Theodoret of Cyrus, Historia ecclesiastica V 38,2 (GCS Theodoret, 342,7-10 Parmentier/Hansen). 
that in the Eranistes, which is often described as irenic, it is in fact this group of Apollinarians within the majority church that Theodoret is most likely addressing. ${ }^{11}$ The quotations of Apollinarius in all three dialogues of the Eranistes support this assumption. Theodoret concludes his church history with mention of both, the tendentially Apollinarian Theodotus of Antioch and Theodore of Mopsuestia, whom Theodoret regarded as a role model.

In 449, at the Robber Synod, Theodoret was accused of having taken up residence in Antioch ${ }^{12}$ under Bishop Domnus instead of performing his duties in Cyrus. Theodoret became the mouthpiece of a church in which not every bishop or cleric identified with Theodore. Our task must be to track down the discursive situations that shine forth from the divers theological texts, to gain a more nuanced picture of the theological positions expounded in Antioch, and, finally, not only to investigate how the union of the two natures is conceptualized within a given Christology, but to identify which topics were of most concern to the theologians in Antioch.

Scholars have generally approached Theodoret's theology on the basis of three short pseudonymous texts, namely Ps. Justin, Expositio rectae fidei, ${ }^{13}$ Ps. Cyril, De Trinitate and De incarnatione. ${ }^{14}$ Whether Ps. Justin was in fact written by Theodoret is more than doubtful. ${ }^{15}$ There are better arguments for the attribution of Ps.Cyril to Theodoret. But I am going to restrict myself to three major texts whose attribution to Theodoret is uncontentious, and which are not primarily concerned with Christology. In the following I will focus on only one dogmatic topic to convey the theological profile of Theodoret.

Theodoret gave a fairly detailed account of his views on God's providence on three occasions, first in the Graecarum affectionum curatio, ${ }^{16}$ then in the De providentia orationes decem ${ }^{17}$ and finally in the Haereticarum fabularum compendium. ${ }^{18}$ The Graecarum affectionum curatio is usually regarded as the earliest, and the Haereticarum fabularum compendium as one of the last of Theodoret's works. In these texts he provides an overall theological survey and in both of them the doctrine of divine providence plays a key role in the transition from the doctrine of Creation to Christology, but also from the doctrine of Creation to ethics, to the veneration of martyrs and to asceticism. Let's begin with the earliest treatment of the topic.

11. S.-P. Bergian, Theodoret von Cyrus, Apollinarius und die Apollinaristen in Antiochien. Zur Interpretation der Schrift »Eranistes «, in: S.-P. Bergjan, B. Gleede, M. Heimgartner (ed.), Apollinarius und seine Folgen, STAC 93, Tübingen 2015, 229-258.

12. On Antioch cf. F. Krautheim, Das öffentliche Auftreten des Christentums im spätantiken Antiochia. Eine Studie unter besonderer Berücksichtigung der Agonmetaphorik in ausgewählten Märtyrerpredigten des Johannes Chrysostomos, STAC 109, Tübingen 2018.

13. Ps.Justin, Expositio rectae fidei, in: Iustinii philosophi et martyris opera quae feruntur omnia, ed. J. C. Th. Otto, Vol. 3,1, CorpAp 4, Jena ${ }^{3} 1880,2-66$.

14. Ps-Cyril, De trinitate et incarnatione, PG 75, 1147-1190, 1419-1478.

15. J.-N. Guinot: L' «Expositio rectae fidei« et le traité »Sur la Trinité et l'Incarnation « de Théodoret de Cyr. Deux types d'argumentation pour un même propos?, in: RechAug 32, 2001, 39-74.

16. Théodoret de Cyr: Thérapeutique des maladies helléniques, ed. P. Canivet, 2 vols., SC 57, Paris 1958. English Translation: Theodoret of Cyrus. A Cure for Pagan Maladies, trans. by Th. Halton, ACW 67, New York 2013.

17. Théodoret de Cyr: Discours sur la providence. Traduction avec introduction et notes par Y. Azéma (Paris 1954). English Translation: Theodoret of Cyrus, On Divine Providence, transl. by Th. Halton, ACW 49, New York 1988.

18. Haereticarum fabularum compendium, PG 83, 336-556. 
The quotations from the »sick Hellenes ${ }^{19}{ }^{19}$ immediately demonstrate that Theodoret had read Clement of Alexandria and Eusebius of Caesarea and gleaned some of his material from them. It can be shown that Theodoret had direct knowledge of texts that he relied on. He also used and explicitly named doxographic handbooks. However, setting aside the origin and specific form of quotions, it would be interesting to gain a more precise picture of the continuing effect of the conceptions of Clement and Eusebius on Theodoret.

The sixth book of Theodoret's Curatio is devoted to God's providence, but the topic appears earlier. In book 3, on angels, gods and demons, Theodoret writes that according to Scripture invisible forces exist and their task is to praise God and serve Him (cur. 3,88). Certain human beings, namely the ascetics, emulate these invisible and thus incorporeal forces. This might bring Clement to mind. Do these servient forces implement divine providence and are the ascetics Clement's gnostics, who carry on the angels' pronoia? (cur. 3,92) In book 3 Theodoret explains that the incorporeal powers, which were created in thousands in the beginning, are »ordered by the will of God and sent by the God of All for the sake of humankind « (cur. 3,91), and that by the angels' care the Creator keeps watch over the human race. (cur. 3,102) Here Theodoret comes very close to the concept of the individual Pronoia, without however using the terminology of Ps. Plutarch, for example. He makes up for this in book 4, on matter and the cosmos, in a report on Platon and his accordance with "us «. There we read, that invisible forces »had been assigned the task of administering certain parts of Creation «. (cur. 4,45) But this is only a report rather than his own statement. In Book 6, on divine providence, however, there is no examination whatsoever of the distinction between general and individual providence, in other words whether and if so how God's providence reaches the individual. Instead the text explains how we might envisage this divine route to individual human beings christologically. When it comes to the doctrine of providence, Theodoret is chiefly concerned with the dissatisfied, who hold God responsible for what happens, criticize the Creator and his providence and put everything down to inescapable fate. Handbook-knowledge of Epicurus and Aristotle shows up: the former's assertion that the gods care nothing for human beings and their affairs, and the latter's conception of a providence that extends only as far as the moon. (cur. 6,6) But the doxographical account breaks off with Aristotle, and the sequel is worked out in his own words. Theodoret mentions Dike, Lachesis and Clotho and turns to the theme of Heimarmene, or to be more precise to the fundamental difference between Heimarmene and providence, and discusses the Stoics, who are unaware of this difference or seek to level it out.

The statements on Tyche are equally contradictory according to Theodoret. This includes among other things the insight that nothing is subject to chance, that God sees everything and dispenses justice to all in a last judgement, and that no one escapes punishment. This takes us back to the critics of providence and to Theodoret's main concern. He cites Plato's remarks on the purpose of punishments either as instructional measures or as a form of deterrence, in order to defend, with Plato, the meaningful arrangement of the cosmos as a whole, represented by the idea of divine

19. Numerous literal quotations in the Curatio have been identified, among them a significant number of Plato reference, cf. P. Canivet (Théodoret de Cyr: Thérapeutique des maladies helléniques, Vol. 2, 451-466. Cf. also the introduction by Clemens Scholten in: Theodoret von Cyrus, De Graecarum affectionum curatio: Heilung der griechischen Krankheiten, eingeleitet und übersetzt von Clemens Scholten, SVigChr 126, Leiden 2015. 
providence. While injustice and misfortune undoubtedly exist and are not restricted to the wicked, Theodoret tells us that it would be quite wrong to describe God as unjust. (cur. 6,42) ${ }^{20}$ Theodoret defends social distinctions and the necessity for the existence of both rulers and subordinates against those who deny any purpose to poverty, illness and slavery and demand that everyone should share in prosperity. (cur. 6,62) Theodoret fends off these challenges, finding support in Plotinus. With reference to Eusebius's history of the church, Theodoret dates Plotinus to the time of Origen and finds areas of agreement with Christian belief. He does not find Plotinus in the Praeparatio Evangelica. Theodoret clearly has Ennead III 2 in front of him and quotes from it extensively, as in the following example:

For it produced a whole, all beautiful and self-sufficient and friends with itsself and with its parts, both the more important and the lesser, which are all equally well adapted to it. So he who blamed the whole because of its parts, both the more important and the lesser, which are all equally well adapted to it. Would be quite unreasonable in his blame; one must consider the parts in relation to the whole, to see if they are harmonious and in concord with it; and when one considers the whole one must not look at a few little parts « ${ }^{21}$

Theodoret is entirely convinced that within the cosmos as a whole the individual parts make sense and must be accepted in all their diversity. Origen would have taken a different view and would have brought up the issue of social inequality.

In Curatio VI we also find Theodoret's well-known, possibly earliest statements on Christology as part of God's providence. Theodoret's main point right from the start is that the incarnation of the Logos differs fundamentally from a mere annihilation of

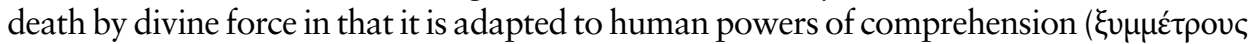

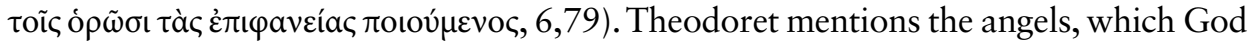
does without. Everything points to the fact that the incarnation performs the function of individual providence, in which the providence of God most high reaches the individual human being through intermediary beings. It is not until the De providentia orationes decem that Theodoret writes this explicitly: "Let us admire him for not entrusting our cure to angels, but instead taking the treatment of humankind upon himself. « (or.10, 749C) Theodoret stands in the tradition of Eusebius in seeking to tie Christology to the doctrine of providence. This is already evident in Curatio VI. Theodoret writes: »It would have been easy for him to bring about the salvation of humankind without this veil of flesh ... It was not his power that he wished to demonstrate, but the just nature of providence. «(cur. 6,78) 22 This must be understood as a reference to the fact that the

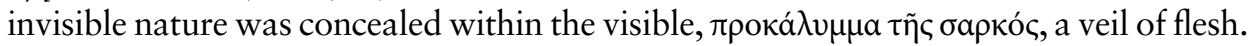
Incarnation is bound up with God's becoming visible. The metaphor of the veil and of the tent seems to be an Antiochene tradition. Only once and in exactly this context Theodoret uses the contrast between ä $v \theta \rho \omega \pi \circ \varsigma$ and $\Theta \varepsilon$ co mother he fixed round himself the human tent, emerging from it as a visible human being and adored God «. (cur. 6,79) While Theodoret goes on to expound the unmixed character of the natures this is not associated with observations on the individuality of a human being or with the use of »concrete terms «. Quite the reverse. Theodoret

20. Theodoret draws heavily on Plato, cf. also the quotation from Plato, leg. 899D-902D in cur. 6,43-46. These quotations can be found in Eusebius of Caesarea, PE 12,52.

21. Cur. 6,62: Plotinus, Ennead. III 2,3. Translation: Halton, 150.

22. Compare Halton, 155. 
puts his emphazise on the two natures that remain unmixed and the union that does not pure them together. (cur. 6,80)

Theodoret returns to divine providence on two further occasions, particularly in the Ten Discourses on God's pronoia. In these discourses, Theodoret generally does without the philosophical doxography. His focus of attention is on those who deny and criticize divine providence, though he does not identify them with Epicurus. This is surprising in a book of this length and scope and suggests that it was written for a particular reason. Theodoret found himself confronted with critics who could not be answered with handbook knowledge. But the classical doctrine of pronoia is evident in the structure of the discourses. The discourses move from the universal, namely the world of the stars, the order of the cosmos, to the microcosm of the human being, and then on to concrete living condition, namely to the problem of poverty and wealth as a supposed challenge to the notion of divine providence.

Theodoret is concerned with the order inherent in the world as God's Creation and the relatedness of individual things to the whole, which gives individual things their meaning in all their diversity. The well-ordered character of the cosmos is reflected in the micro-cosmos of the human being. There are very few writings in which Theodoret goes into such a plethora of medical details. Oesophagus and spinal marrow, cranium and brain, eyes and eyebrows are mentioned. Theodoret identifies criticisms of the concept of providence with pointing out the lack of order. But as Theodoret shows, the human body is well-equipped and stands in a reciprocal relationship to the organs, which enable it to carry out various tasks. This is where Theodoret begins to criticize those who are unpersuaded by these ideas. At issue here are people's living conditions within society. Theodoret legitimizes the existence of master and slave or servant. He writes an apology for the rich and mighty who according to Theodoret, society needs. He points out their dependence on slaves and servants and depicts an idyll of simple life and poverty, as can be found in writings of the Second Sophistic. Theodoret may be admitting the reality of poverty to a certain degree when he writes: »The poor man, on the other hand, has only a single hovel, generally a rented one. Indeed some who cannot pay the rent live in the marketplace with the ground as a bed and chaff as a mattress. No doctor stands by them, no cook carries out the doctor's order, no housekeeper, no maid, maybe no wife. The providence of God does all for him ... You will notice that a man lying in the open endures illness more readily than those who enjoy all the attention I have spoken about." (or. 6, 664D-665A ${ }^{23}$ The topic of poverty crops up in Curatio VI as well, but takes center stage in the Discourses - for a very specific reason. This, at least, is the implication of the appendix to the monastic history. Here, critics again highlight poverty and deny that the ascetics are accomplishing anything special, suggesting that they are merely doing voluntarily what the poor are forced to do. Theodoret responds:

"None of those who want to criticize us may bring forward farm workers, shepherds and sailors and thus attempt to belittle the struggles of the greatest of these fighters. If the farmer has worked hard by day, at night he is looked after at home, and his wife provides him with all care. In the same way the shepherd has a share allotted in all the things that we have mentioned. $\ll^{24}$

23. Translation: Halton, 86.

24. Théodoret of Cyrus. Histoire des moines de Syrie, ed. P. Canivet/ A. Leroy-Molinghen, vol. 2, SC 257, Paris 1979, 31, 3, 14-17. 
Elements of this pastoral romanticism are also found in the Discourses. Theodoret writes an apologia for the existing order. It has to be seen as part of Theodoret's theology that he justifies slavery, power, domination, obedience and subordination as being necessary. The difference between rulers and ruled, according to Theodoret, did not obtain from the beginning, but first came about after human beings abused their free will. This does not mean that he disputes that power is sometimes exercised unjustly. According to him, however, injustice is punished, in such a way that the doctrine of judgement and resurrection builds directly on the doctrine of providence.

Providence, in other words God's caring ( $\kappa \eta \delta \varepsilon \mu o v i ́ \alpha)$, makes itself evident in the incarnation above all. (or. 10, 745C) Again Theodoret states that the doctrine of incarnation must begin with the conviction that God did not use a powerful intervention to save human beings, but instead he united the defeated human nature with himself, that is, he reentered the battle at the very point of defeat. To do so, he "wore" a human nature. His christological explanations lead Theodoret to a number of metaphors. The sun that renders dirt visible itself receives no stain. The physician doesn't get infected by treating the sick. (or. 10, 748D-749A, 749C) Correspondingly, the divine nature cannot be altered, but remains incorporeal, impassible and unchangeable. To explain the singular way in which human and divine nature come together in Christ Theodoret uses in the Discourses, as in other writings and as other Antiochian authors do, the a $\gamma \hat{\gamma} v$-metaphor. This metaphor evokes the biblical history of temptation. (or. 10, 752B-753B) In this story Jesus remains steadfast against the temptations of the devil as nobody before was able to do. The struggle between Jesus and the devil - Theodoret speaks of the tyrannos or opponent - is identified as a battle, to be precise as a wrestling match in a stadium with the angels as spectators and located in the desert. Christ fought the battle in his human identity - otherwise it would not have been a battle but an act of divine power. But was the opponent misled in that he thought he was tempting a man but unexpectedly it was really the God Logos? The divine aspect seems to have retreated less than in other Antiochene interpretations of the history of temptation. In Theodoret's interpretation the Devil has very little self-confidence, is afraid of the wrestling match, appears reluctant, and needs to be assured or tricked into believing that he is combatting a human being. But, was it a struggle against a human? While the Devil is described as afraid, the man he faces is said to not be frightened but pushes him to take up the battle. The divinity in Christ does not fight the battle, but "not being afraid " appears as a divine attribute because » the judge of the contest does not fear the opponent «. (or. 10, 752B) The Devil believes he is fighting another battle against Adam, but instead found the creator of Adam who had »the nature of Adam put around him «.

This nuanced, balanced relationship between the two natures leads Theodoret back to the role of the humanity in Christ. He draws attention to the biblical text according to which Jesus answers the second and third attack of the Devil as a human being and - his divine nature being kept hidden - thereby achieves by likeness the victory for all humans. The importance given to this last line of thought can be deduced from the fact that Theodoret used a very similar formulation, the like is cured by

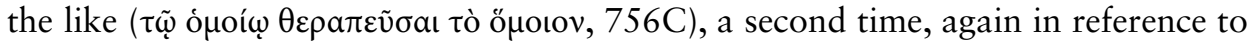
the humanity in Christ.

Let us turn to the third text, which summarizes the doctrine of providence, the Haereticarum fabularum compendium. Here again, the doctrine of providence segues 
into Christology. This is a late text, and Theodoret refers back to De providentia orationes decem. I shall leave the doctrine of providence to one side and directly address his Christology. The point of departure is the name of Christ and his being anointed by the Holy Spirit. The Antiochian origin of his line of argument is clearly recognizable: "But he was anointed not as God, but as a human being (äv $\theta \rho \omega \pi \mathrm{s})$ ). If he was

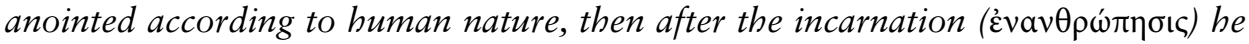
was called Christ. Equally so, it is not the case that one was God Logos and another was called Christ. Because God Logos who became man, was called Christ Jesus. He became man so that the nature that was destroyed by sin be restored. This is why he took on the entire nature that has sinned, so that this entire nature is saved. This is why he took on the nature of the body and did not use it as a means of concealing his divinity as Arius and Eunomius had claimed, for he could have appeared without a body easily... He wanted the weakened nature to lead the battle against the enemy and achieve victory. "(489D-492A). Theodoret expresses himself differently than many years earlier in the Curatio: but the continuity cannot be denied. The uninhibited

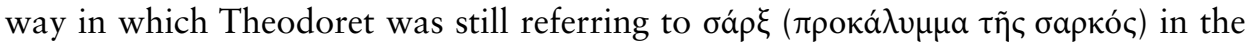
Curatio is gone. Theodoret distances himself from christological concepts expressed with the image of tent or veil. There were obviously other groups that spoke of the concealment of divinity. Instead Theodoret concentrates entirely on incarnation ( $\dot{\varepsilon} v a v \theta \rho \omega \dot{\pi \eta} \sigma \iota \varsigma)$ as the assumption of a fully human nature and again refers to his fundamental conviction that "the like was cured with the like and through the first-

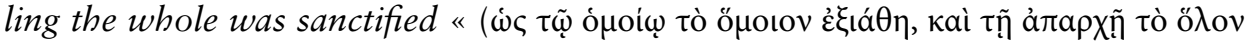
$\dot{\eta} \gamma ı$ cá $\theta \eta$ 493A). ${ }^{25}$ It is easy to see the Antiochene concerns in this later text, in which Theodoret retreats entirely to biblical quotations. The point of departure here is not the divine subject of the Logos, but the incarnated one, in other words Christ. The basic belief is that in Christ the human being or the human aspect has a soteriological significance and that through Christ the human being overcomes $\sin$.

In the 430s Theodoret exchanged letters with members of the group of bishops who were opposed to the peace with Cyril and continued to support Nestorius. Theodoret was for a long time closer to this group than he was to John of Antioch, who soon wished to enforce the peace. The fact that the Haereticarum fabularum compendium as it is printed in the Patrologia Graeca includes a chapter on the "heretic " Nestorius has always been a stumbling block for the interpretation of Theodoret's thinking. This obstacle can be removed, as will be shown in the forthcoming new edition of the text. ${ }^{26}$

25. Cf. the quotation of Gregory of Nazianzus in Theodoret of Cyrus, Eranistes, Florilegium I,47 (Theodoret of Cyrus. Eranistes, ed.by G.H. Ettlinger, Oxford 1975, 104).

26. B. Gleede/ J. Bieler, Theodoret von Cyrus. Haereticarum Fabularum Compendium (Mendacii et veritatis discretio), GCS, in print. 